\title{
S011 ジェンダー研究者としての男性
}

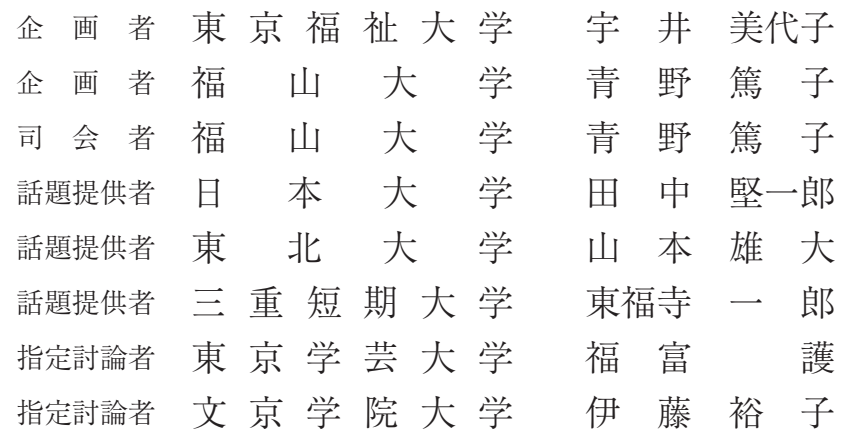

\section{概要}

これまで，ジェンダー研究の担い手の多くは女性研究者であった。しかし，ジェンダーは女性だけの 問題ではない。本シンポジウムでは，ジェンダーの視点から研究を続けてこられた男性研究者の方々 に，これまでの研究知見と男性がジェンダー研究に取り組むことの意義や今後の展開についてご指摘い ただく。なお，これは日本心理学会ジェンダー研究会公開研究集会を兼ねるものである。

職場でのハラスメントについての『認識の溝』(田中堅一郎)

職場に扔けるハラスメントについての研究から見えてくる問題をとりあげる。女性と男性間はいうま でもなく，女性間でも「ハラスメント」について認識のズレが見られ，職場に抒けるハラスメントが 「男性加害者一女性被害者」という図式では十分に捉えきれないことを実感させられる。ジェンダー心 理学に期待することをコメントしたい。

セクシズムの研究を通して（山本雄大）

女性に対する援助や保護として表出される慈悲的性差別の有害な効果について話題を提供する。とり わけ，慈悲的性差別に対する女性の期待が，ジェンダーステレオタイプを維持・正当化する可能性につ いて詳しく言及していく。これらの実証的知見を通して，受容者である女性の意識変化も必要であるこ とを,「男性」研究者の立場から指摘していきたい。

男女共同参画の教育を通して（東福寺一郎）

男女共同参画に関わる学生の意識調査から, 家庭科の男女共修世代であるものの, 「男は外で仕事, 女は家で家事や育児」という意識が払拭されていないことがわかる。男女共同参画社会基本法が施行さ れてから 10 年が経過するが, GEM は下落の一途をたどっている。こうした現状に, 心理学者として どのように向き合うべきなのかという問題を提起したい。 